Procain. 等の局所麻醉剤を混入し、その効力を判定 した。

麻醉の効力は一定間隔で腓腹筋の電気刺戟 学行な いその變縮の状態により判定した。な和ての実験に 用いた局所麻酥菒は市販のままのもの、または臨床で 使用するままのものを用いその混入量のみ加減し た。従つて Citanest は $3 \%$ 、Xylocain, Procain は $2 \%$ あり、また Adrenaline などの含有量は局所 麻䣦桼によって異なっている。

実験結果は以下のようであった。

1）各々の局芹麻醉剂觉灌流液に混入した場合、同 一の薬物間では戀縮高は注入量に正確に逆比例して低 くなった。

2) 今回用いた局所麻醉剂中では Citanestは Xylocain に次ぐ效力走した。

3） Citanest は麻䣲の持続時間が他のものよりも 長いととが認められた。

\section{0. 麻酔用点滴瓶の工夫}

口外 古本克磨、西 正勝

現今、全身麻醉は一般に閉鎖循環式気管内法一辺倒 の感があるが、小児、乳児に対する開放点滴による麻 醉も、実施方簡単であうて、呼吸抵抗も少なく、機械 的死腔も少ないという点で捨て難いものがある。私た ちは、気管内麻醉を行なう導入段階あるいは短時間処 置荧行なう場合の乳幼児の全身麻醉比当って、エーテ ルの開放点滴法を採用しているが、從来の瞄製点滴㧚 に二、三の工夫を施して好結果を得ているので報告し た。

\section{1. 料科用レジンの溶媒による変化}

$$
\text { 理 工 林一郎、井上勝一郎 }
$$

歯科用レジンに対する溶媒の作用は、すでにわれわ れの教室に扔いても、その膨潤による形態の変化とし て肉眼的あるいは顕微鏡的に観察し発表されている。

しかしてれはただ膨澖あるいは崩裱の状態を観察した

\section{9. 動物実験による局所麻酔剤 Citanest の効} カについて

生 理 野代平治、中原 敏

最近、局所麻酔薬 Citanest を入手したので、その 効力テストの一端として、次のような突戨を行ない、 いささか結果を得たので発表する。

実験はガマの下肢灌流荧流速がいっも一定になるよう にして行ない、その灌流液中に Citanest, Xylocain,
に止まり、溶媒の作用气れ自体を推測するには不充分 と考えられる。作用した溶媒を取り去って後にレシシン の性質の変化を調べるととにより始めて純粋に溶媒の 作用をみるととが出来るという考えから、溶媒浸漬後 1 週間放置して完全に恒量となるのを待って、レオ口 ジカルな性質の変化を検討した。その結果、四要素模 型をつくるととが出来、その粘膜部分が大きな変化を 受けるととがわかった。顕微鏡像の観察と合わせ考元 ると、粉液成型に由来する境界線とは関係なしに小割 れがあるととから、もつと小さな単位に执いて大り組 んだ粘性構造と弹性構造が存在するものといえるよう である。

有機ガラスについて同様の実験を行なうてとを計画 中であるが、とれにより、さらにわれわれの考えが確 汃められるものと思う。

\section{2. わが教室における過去10年間の補綴物の統計} 鶴島角岩、住田光信、伊脉好二、 内田康世、魏吉利助、野正哲夫、 浦池徾志、椛田治夫、尾上考栄

今回は有床義歯について重点的に調查しました。

Full Denture は上顎のものが多く下顎の約 1.2 倍

Partial Denture は下顎のものが多く上顎の約 1.4 掊を示した。

Partial Denture に扣ける Bar Denture の占る 割合柱全体の $25 \%$ 、との内上顎は $18 \%$ 、下顎では $34 \%$ 走し Bar の使用頻度は下顎が上顎よりも約 2 倍多 くなっている。

また下顎では偏側連結型の症例が多い。下顎では上

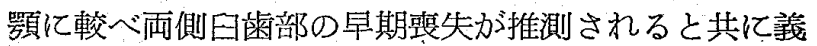
䨑設計上、形態的にも機能的にも Bar Denture の 適応例の多いことが裏付けられる。

\section{3. 抜歯創への骨小片移植に関する実験的研究} (第1報)

$$
\text { 口外旦山保 }
$$

抜崡創の治瘾機転に関する研究は、比較的古く汃ら 近年にいたるまで、実験的にも臨床的にも幾多の研究 が西るが、抜歯創一、直接、骨小片の充填移植学行な つた実験的研究は、本邦に扔いては、高橋の研究をみ るのみである。私は、骨小片移植による抜歯創の即時 形成に関する実験を試みたので、今回は、その一端を 報告する。

成犬の下顎大臼崡部总抜去し、乙れに対して、第 1 